\title{
Incidentally discovered urachal cancer in a patient with necrotising fasciitis of the abdominal wall
}

\author{
Nathan Shaw, ${ }^{1}$ Daniel Marchalik, ${ }^{2}$ Lambros Stamatakis ${ }^{3}$
}

${ }^{1}$ University of Virginia School of Medicine, Charlottesville, Virginia, USA

${ }^{2}$ Department of Urology, MedStar Georgetown University Hospital, Washington DC, USA ${ }^{3}$ Department of Urology, MedStar Washington Hospital Center, Washington DC, USA

\section{Correspondence to} Dr Daniel Marchalik, dan.marchalik@gmail.com

Accepted 15 April 2016
CrossMark

\section{To cite: Shaw N,} Marchalik D, Stamatakis L. BMJ Case Rep Published online: [please include Day Month Year] doi:10.1136/ bcr-2015-213226

\section{DESCRIPTION}

Urachal cancers are rare, accounting for $<0.7 \%{ }^{1}$ of all bladder cancers, and the majority $(>90 \%)$ are adenocarcinomas. ${ }^{2}$ We describe a case of a patient with poorly controlled diabetes presenting with a 4-day history of an expanding, painful abdominal rash. CT scan performed on admission demonstrated an umbilical hernia (figure 1A) consisting primarily of fat and a $7 \times 5 \times 7 \mathrm{~cm}$ mass (figure 1C), radiographically consistent with a tumour. Given a clinical picture consistent with necrotising fasciitis (tachycardia, marked leucocytosis, and expanding erythaema and crepitus of the abdominal wall), the patient underwent extensive surgical debridement. Intraoperative cultures confirmed methicillinresistant Staphylococcus aureus. Pathological evaluation revealed moderately differentiated papillary carcinoma with urothelial and squamous differentiation most likely of urachal origin (figure 1B). Cytopathological staining was positive for CD7, CD5/6, P63 and GATA 1 , and was negative for CDX2 and uroplakin; CK20 and 34BE12 stains were not performed. The patient's hospital course was complicated by cardiac arrest with cardiopulmonary resuscitation and long-term ventilation. Owing to the severity of her condition, cystoscopic evaluation was not performed. The patient underwent multiple subsequent debridements and the prognosis remained poor at the time of writing.

Urachal cysts have been reported as the source for abdominal wall infections, ${ }^{3}$ but urachal cancer as a nidus has not been described. The role of the patient's tumour in the development of the lifethreatening infection remains unclear.

\section{Learning points}

Keep rare cancers as a differential for common findings (umbilical hernia).

- Caution should be paid to tissue discovered during emergent operations.

- Send suspicious tissue to pathology.

Acknowledgements The authors would like to thank Dr Jayashree Krishnan (pathology) for her assistance with the case.

Contributors NS, DM and LS designed the report, conducted the research, drafted and revised the manuscript.

Competing interests None declared.

Patient consent Not obtained.

Provenance and peer review Not commissioned; externally pee reviewed.

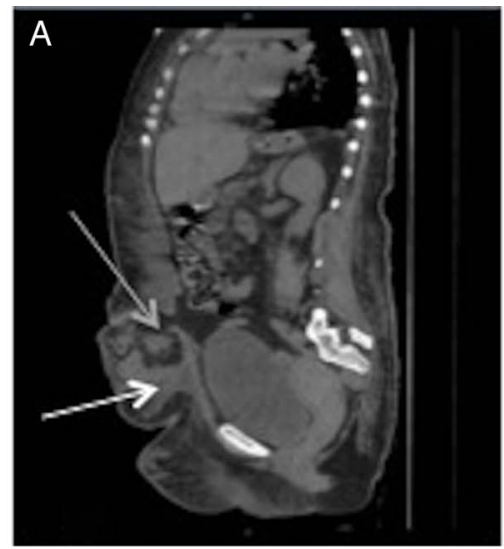

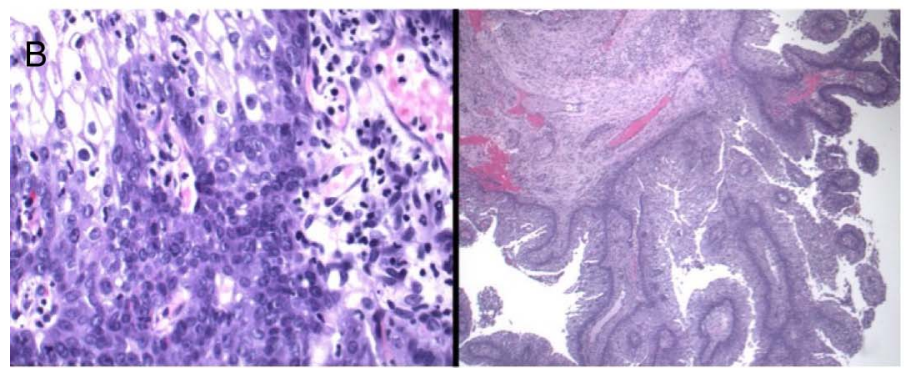

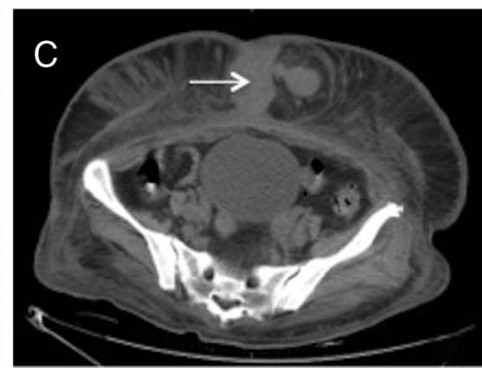

Figure 1 (A) Sagittal CT showing large mass (white arrow) and abdominal wall defect (grey arrow); (B) high-power view of moderately differentiated papillary carcinoma with urothelial and squamous feature; (C) axillary CT showing discrete solid mass within large umbilical hernia. 


\section{REFERENCES}

1 Molina JR, Quevedo JF, Furth AF, et al. Predictors of survival from urachal cancer: a Mayo Clinic study of 49 cases. Cancer 2007;110: 2434-40.
2 Wright JL, Porter MP, Li Cl, et al. Differences in survival among patients with urachal and nonurachal adenocarcinomas of the bladder. Cancer 2006;107:72.

3 Walker C. A case report of urachal abscess: a rare differential in adult abdominal pain. Hawaii Med J 2010;69:35-6.

Copyright 2016 BMJ Publishing Group. All rights reserved. For permission to reuse any of this content visit

http://group.bmj.com/group/rights-licensing/permissions.

BMJ Case Report Fellows may re-use this article for personal use and teaching without any further permission.

Become a Fellow of BMJ Case Reports today and you can:

- Submit as many cases as you like

- Enjoy fast sympathetic peer review and rapid publication of accepted articles

- Access all the published articles

- Re-use any of the published material for personal use and teaching without further permission

For information on Institutional Fellowships contact consortiasales@bmjgroup.com

Visit casereports.bmj.com for more articles like this and to become a Fellow 